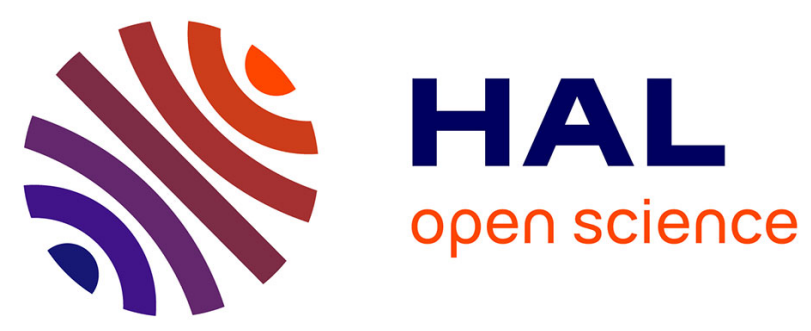

\title{
Limestone assimilation by basaltic magmas: an experimental re-assessment and application to Italian volcanoes
}

\author{
Giada Iacono-Marziano, Fabrice Gaillard, Michel Pichavant
}

\section{To cite this version:}

Giada Iacono-Marziano, Fabrice Gaillard, Michel Pichavant. Limestone assimilation by basaltic magmas: an experimental re-assessment and application to Italian volcanoes. Contributions to Mineralogy and Petrology, 2008, 155 (6), pp.719-738. 10.1007/s00410-007-0267-8 . insu-00194400

\section{HAL Id: insu-00194400 \\ https://hal-insu.archives-ouvertes.fr/insu-00194400}

Submitted on 6 Dec 2007

HAL is a multi-disciplinary open access archive for the deposit and dissemination of scientific research documents, whether they are published or not. The documents may come from teaching and research institutions in France or abroad, or from public or private research centers.
L'archive ouverte pluridisciplinaire HAL, est destinée au dépôt et à la diffusion de documents scientifiques de niveau recherche, publiés ou non, émanant des établissements d'enseignement et de recherche français ou étrangers, des laboratoires publics ou privés. 


\title{
Limestone assimilation by basaltic magmas: an experimental re-assessment and application to Italian volcanoes
}

\author{
Giada Iacono Marziano $^{\mathrm{a}, \mathrm{b}}$, Fabrice Gaillard*a,c ${ }^{\mathrm{a}}$ and Michel Pichavant ${ }^{\mathrm{c}}$ \\ ${ }^{\text {a }}$ Bayerisches GeoInstitut, Universtat Strasse, 95444 Bayreuth, Germany \\ ${ }^{\mathrm{b}}$ Istituto Nazionale di Geofisica e Vulcanologia, sezione di Palermo, via Ugo La Malfa 153, 90146 \\ Palermo, Italy \\ ${ }^{\mathrm{c}}$ Institut des Sciences de la Terre d'Orléans (ISTO), UMR 6113 CNRS, 1A rue de la Ferollerie, 45071 \\ Orléans CEDEX 2, France
}

* Corresponding author 
The results of an experimental study of limestone assimilation by hydrated basaltic magmas in the range $1050-1150{ }^{\circ} \mathrm{C}, 0.1-500 \mathrm{MPa}$ are reported. Alkali basalts doped with up to $19 \mathrm{wt} \%$ of Ca,Mg-carbonates were equilibrated in internally heated pressure vessels and the resulting phase relationships are described. The major effects of carbonate incorporation are: 1) generation of $\mathrm{CO}_{2}$-rich fluid phases; 2) change in liquidus phase equilibria; the crystallization of Ca-rich clinopyroxene is favored and the other phases (e.g. olivine, plagioclase), present in the absence of carbonate assimilation, are consumed. As a consequence of the massive clinopyroxene crystallization, the residual melt is strongly silica-depleted and becomes nepheline-normative. Compositional and mineralogical evolutions observed in Mt.Vesuvius eruptive products match those documented in our experiments with added carbonates, suggesting the possibility that carbonate assimilation increased during the last 25ka of activity. In Central-Southern Italy, carbonate assimilation at shallow levels probably superimposes on deeper source heterogeneities.

\section{Introduction}

Daly (1910) first proposed that alkali-rich, desilicated magmas could be generated by assimilation of sedimentary carbonates. The desilication of the magma was suggested to be a consequence of limestone dissolution in the magma accompanied by pyroxene crystallization (Daly 1910). Such a mechanism was mainly deduced from the frequent association between alkaline magmas and carbonate rocks (marble, limestone). Since 1910, this carbonate assimilation hypothesis has been vigorously debated by means of numerous field and experimental studies. Despite numerous descriptions of basaltic intrusions in carbonate rocks showing clear magma-limestone exchanges with silica-depletion of the residual liquid (Daly 1910; Rittmann 1933; Shand 1945), Daly's hypothesis was mainly discarded on the basis of few experimental studies on simple synthetic compositions, which are summarized in Wyllie (1974). In brief, such studies showed that a transition from "granitic" to "feldspathoidal" liquids (i.e. over-saturated to under-saturated in silica, in the sense of Peccerillo 2005a) by limestone assimilation was precluded by the existence of a thermal barrier (Watkinson and Wyllie 1969). Following these studies, limestone assimilation was therefore relegated to a very local process, merely restricted to the vicinity of the side-wall and unable to significantly 
affect the whole magma body. From a geochemical point of view, the distinctive trace elements and isotopic signature of alkaline magmas has been interpreted in terms of deep source heterogeneities, rather than of shallow carbonate assimilation (Foley 1992; Buhn and Trumbull 2003). The current dominant viewpoint attributes the origin of silica-undersaturated alkaline magmatic suites to melting of heterogeneously enriched mantle regions (Wyllie 1974; Thibault et al. 1992; Foley 1992; Buhn and Trumbull 2003; Elkins-Tanton and Grove 2003). However, some recent petrological studies have documented in details the effects of carbonate assimilation by magmatic dikes intruding limestone or marble series (Baker and Black 1980; Wenzel et al. 2002; Barnes et al. 2005 and references therein, Coulson et al. 2007). Magma contamination is marked by the overgrowth of Ca-rich phases (mainly calcic clinopyroxene, but also Ca-amphibole, wollastonite, scapolite, grossular-rich garnet, etc.) on primary minerals (essentially olivine); as a result, the magma becomes progressively depleted in silica and enriched in alkali (Baker and Black 1980; Barnes et al. 2005). These interactions are mostly described at the meter scale; however they affect plutonic bodies up to several kilometers wide, and degrees of assimilation of carbonate rocks in the range of $20 \mathrm{wt} \%$ or higher have been proposed (Barnes et al. 2005). Such studies clearly show that previous conclusions about the negligible importance of carbonate assimilation need to be re-evaluated. In this paper, we first re-examine experimentally the mechanism of carbonate assimilation by basaltic magmas. Second, we use the magma compositions erupted by Italian volcanoes to test limestone assimilation as a possible natural differentiation mechanism. The widespread presence of limestone and dolostone in the sedimentary basement ( 5 to $20 \mathrm{~km}$ thick), the abundance of high temperature skarns in the eruptive products and the important $\mathrm{CO}_{2}$ emissions make carbonate assimilation a possible process occurring in the plumbing system of Italian volcanoes (Iacono Marziano et al. 2007).

\section{Experimental and analytical methods}

\subsection{Starting materials and strategy}

The experiments were performed on two natural basalts from Stromboli volcano (Aeolian Islands, Italy), ST18 and PST9. The selected basalts, which represent two of the most primitive products from the recent activity of this volcano (Peccerillo 2001; Di Carlo et al. 2006), are among the few primitive compositions available in Italy that are close to silicasaturation. Stromboli is seated on a thin continental crust supposedly devoid of sedimentary 
carbonate rocks (Bonardi et al. 2001). The two chosen basalts can therefore be considered as representative of liquids that did not experience carbonate assimilation. Recent volcanic products of Stromboli share many geochemical features with the magmas of the Campanian Province, particularly Mt. Vesuvius (Peccerillo 2001). However, in contrast to Campanian volcanoes, Stromboli does not emit strongly silica-undersaturated magmas. Both starting basalts are indeed nearly silica-saturated and alkali-rich (Tables 1-2). The shoshonitic composition (ST18) has a higher $\mathrm{K} / \mathrm{Na}$ ratio than the high-K calc-alkaline one (PST9). The $\mathrm{CaO}$ content is higher in PST9 than in ST18.

San Carlos olivine ( $\mathrm{Fo}_{91}$ ) was added in selected runs (\#7 and \#8) to adjust the $\mathrm{MgO}$ content of the starting bulk silicate composition to the most primitive melt inclusions found in volcanic products of Central-Southern Italy (ca. 9-10 wt \%; Marianelli et al. 1995; Kamenetsky et al. 1995). To investigate the consequence of different degrees of carbonate assimilation on basalt phase relations, variable amounts of $\mathrm{Ca}$ - and $\mathrm{Mg}$-carbonate were systematically added to the silicate component. Pure Ca-marble from Carrara (Italy) and synthetic Mg-carbonate were used in various proportions (Tables 1-2). The amount of added carbonates ranged from 0 to $19 \mathrm{wt} \%$ of the total charge. For most experiments, 1-3 wt $\%$ water was added, encompassing the range of water content in most primitive melts found in Central-Southern Italian volcanoes, such as Mt. Vesuvius (Marianelli et al. 2005). In addition, the effect of water on the mechanisms of assimilation was investigated by performing both anhydrous runs (\#1 and \#2) and water-rich runs in which between 4-5 wt $\%$ (\#4 and 5) and 5-6wt $\%$ water was added (\#3).

This study is aimed at the experimental characterization of the process of carbonate assimilation by mafic magmas in general. Experimental variables considered include the magma composition of the magma (in particular the alkali and $\mathrm{MgO}$ contents), the pressure, the temperature, the water content, and the $\mathrm{Mg}$ content of the carbonate.

\subsection{Experiments}

The effects of carbonate assimilation were essentially examined at moderate pressures and in presence of water (Table 1 and 2). A pressure of $200 \mathrm{MPa}$ was adopted for most experiments (run \# 4, 5, 6, 7 and 8), which is consistent with an average depth of crustal magma storage beneath Italian volcanoes mostly between 3 and $10 \mathrm{~km}$ (Barberi and Leoni 1980; Auger et al. 2001; Chiarabba et al. 1997; Marianelli et al. 2005; Di Carlo et al. 2006). A few experiments were also performed at $500 \mathrm{MPa}$ (run \# 3) to test the influence of pressure and of high water 
contents on the carbonate assimilation mechanism. Furthermore, two runs were conducted at 1 atm (run \# 1 and 2) to provide additional information on the effect of pressure and to test the assimilation mechanism in absence of water. The $1 \mathrm{~atm}$ experiments were performed at the Bayerisches Geoinstitut of Bayreuth (Germany) using gas mixing furnaces flushed with Ar$\mathrm{CO}_{2}$ gas mixtures. The carbonate and silicate components were loaded as powders in noble metal crucibles. $\mathrm{Au}_{70} \mathrm{Pd}_{30}$ was selected to minimize $\mathrm{Fe}$ loss. Two temperatures were investigated, 1100 and $1150^{\circ} \mathrm{C}$ (Table 2). Redox conditions were monitored using zirconia electrochemical cells at values close to the Hematite-Magnetite redox buffer. The highpressure experiments were conducted both at the Bayerisches Geoinstitut and at the Institut des Sciences de la Terre d'Orléans (France) in internally heated pressure vessels equipped with rapid quench device (as described in Roux and Lefèvre 1992). Pure Argon was used as pressure medium; no hydrogen was added to Ar and redox conditions are estimated to lie in the range $\mathrm{NNO}+1$ to $\mathrm{NNO}+3$ depending on the amount of water present in the charges (Gaillard et al. 2003). $\mathrm{Au}_{80} \mathrm{Pd}_{20}$ capsules were used as containers. Between 1 to $6 \mathrm{wt} \%$ water was added with a micro-syringe and the carbonate and silicate components were both loaded as powders $\left(50-100 \mu \mathrm{m}\right.$ grain size). Temperatures of 1050,1100 and $1150^{\circ} \mathrm{C}$ were investigated at $200 \mathrm{MPa}$, and of $1050^{\circ} \mathrm{C}$ at $500 \mathrm{MPa}$ (Tables 1-2). Run durations ranged from 5 to 40 hours depending on temperature. Experiments were terminated by drop-quenching the charges (Di Carlo et al. 2006).

\subsection{Analytical methods}

Rapidly quenched run products were observed using optical and electron microscopy (Jeol WINDSET JSM 6400 at Orléans) and analyzed by electron microprobe (Jeol JXA-8200 at Bayreuth and SX 50 at Orléans). Analytical conditions used were $15 \mathrm{kV}, 6 \mathrm{nA}, 10 \mathrm{sec}$ on peak and $5 \mathrm{sec}$ on background. $\mathrm{H}_{2} \mathrm{O}$ and $\mathrm{CO}_{2}$ concentrations were measured by Fourier transform infrared spectroscopy (FTIR) in glasses from run \#4 and \#5 (ISTO, Orléans). These charges are the only ones suitable to FTIR analyses due to their low proportion of crystals. For the other charges, the water content was estimated using the by-difference method (following Di Carlo et al. 2006), with an analytical error of $\sim 1 \mathrm{wt} \% \mathrm{H}_{2} \mathrm{O}$ (Devine et al. 1995).

The FTIR spectra were collected on a Nicolet Magna 760 spectrometer equipped with an IR microscope and an MCT detector. Absorption spectra were acquired with 128 scans and a resolution of $4 \mathrm{~cm}^{-1}$, using a tungsten white light source and a $\mathrm{CaF}_{2}$ beam-splitter for the NIR region and a Globar source and a $\mathrm{KBr}$ beam-splitter for the MIR region. The total water 
content of the glass was determined as the sum of structurally bonded hydroxyl groups and molecular water, calculated from the absorbances of the $4500 \mathrm{~cm}^{-1}$ and $5210 \mathrm{~cm}^{-1}$ bands, respectively, using the Lambert-Beer law. The linear extinction coefficients for these bands were taken from Dixon et al. (1995). Concentrations of dissolved carbonate in glasses were measured from the intensities of the bands at 1515 and $1435 \mathrm{~cm}^{-1}$ using the linear extinction coefficients in Dixon et al. (1995) and Thibault and Holloway (1994). The use of extinction coefficients calibrated for MORB (Dixon et al. 1995) and Ca-rich leucititic compositions (Thibault and Holloway 1994) does not substantially change $\mathrm{CO}_{2}$ determinations (Table 1).

Mass balance calculations were performed to compute proportions of phases present in the charge (glass, minerals but also fluid phase in the case of high pressure experiments) and to evaluate $\mathrm{Fe}$ loss to the capsules. For this purpose, masses and compositions of starting mixtures, and compositions of experimental glasses and mineral phases were used. In the high-pressure runs, the amounts of loaded $\mathrm{H}_{2} \mathrm{O}$ and $\mathrm{CO}_{2}$ (the latter coming from the breakdown of carbonate) were mass-balanced between glass and fluid using $\mathrm{H}_{2} \mathrm{O}$ and $\mathrm{CO}_{2}$ amounts dissolved in the glass measured by FTIR, when available, or $\mathrm{H}_{2} \mathrm{O}$ amounts estimated using the by-difference method (Table 1 and 2) and arbitrarily assigning a $\mathrm{CO}_{2}$ concentration of $0.2 \mathrm{wt} \%$ to the other carbonate-added runs. Although $\mathrm{CO}_{2}$ glass concentrations, determined by FTIR, may reach values up to $0.6 \mathrm{wt} \%$ (Table 1), $0.2 \mathrm{wt} \%$ is considered as a reasonable average $\mathrm{CO}_{2}$ concentration in our high-pressure experimental glasses (see section 3.1). Variations in the $\mathrm{CO}_{2}$ content of the glasses within the measured range $(0.19-0.62)$ have a negligible effect on the mass balance calculations because most of the $\mathrm{CO}_{2}$ partitions into the fluid phase. The most important source of error in these calculations is the water content in the glass, which, propagated through the mass balance equations, gives us an averaged uncertainty of $\pm 1 \mathrm{wt} \%$ on the fluid phase proportion and of $\pm 5 \mathrm{wt} \%$ on the fluid phase composition.

\section{Results}

Tables 1 and 2 summarize experimental conditions, phase assemblages and compositions for the PST9 and ST18 starting materials. A total of 41 experimental charges are reported, including 7 from the $1 \mathrm{~atm}$ experiments, 31 from the ca. $200 \mathrm{MPa}$ experiments and 3 from the $500 \mathrm{MPa}$ experiment. The effects of carbonate assimilation are essentially characterized at a pressure of $\sim 200 \mathrm{MPa}$ and water contents of 1-3 wt\% (runs \#6, 7, 8). These experiments illustrate the variation of phase relations with temperature and carbonate content. Two 
experiments at similar pressure (runs \#4 and 5) but higher water contents (up to $5 \mathrm{wt} \%$ ) present very low crystal contents $(0-8.7 \mathrm{wt} \%)$ and therefore illustrate the near-liquidus magma behavior. Two experiments at 1 atm (run \# 1 and 2) and one at $500 \mathrm{MPa}$ qualitatively illustrate the combined effect of pressure and water content on the carbonate assimilation mechanism.

Experimental samples were all observed to be free of quench crystals on the basis of SEM examinations. Therefore the analyzed glass compositions can be considered as representative of the high-T, high-P melts. Mineral and glass compositions are generally homogeneous for a given sample, except for the clinopyroxene crystals that are sometimes slightly heterogeneous. Calculated crystal-melt exchange coefficients for clinopyroxene $\left(\mathrm{K}_{\mathrm{d}}=[\mathrm{Fe} / \mathrm{Mg}\right.$ in $\mathrm{Cpx}] /$ [ $\mathrm{Fe} / \mathrm{Mg}$ in melt], calculated with $\mathrm{FeO}=\mathrm{FeO}_{\mathrm{tot}}$ ) are similar to those found in a recent experimental study of near-liquidus crystallization of the PST9 composition in hydrous conditions (Di Carlo et al., 2006) and in other experimental studies of hydrous basaltic compositions (Sisson and Grove 1993; Pichavant et al. 2002). This suggests that crystal-liquid equilibrium was attained in our experiments.

Mass balance calculations revealed iron losses to the containers ranging from 0 to $7 \mathrm{wt} \%$, depending on temperature and on redox conditions. This shows that iron loss can be neglected in this study, consistent with the use of Au-Pd containers, the relatively short duration and the oxidizing conditions of our carbonate interaction experiments.

\subsection{Volatiles}

A fluid phase is present in all carbonate-bearing charges from the high-pressure experiments; it appears with the addition of a few weight percent of carbonate and reaches proportions up to $9 \mathrm{wt} \%$ for samples where $21 \mathrm{wt} \%$ of carbonate is added (Table 1-2; Fig.1). Conversely, most carbonate-free charges are fluid-absent (charges 5-1, 6-1, 7-1, 8-1, 6-6, 7-4, 8-4, Tables 1-2) because the amount of loaded water was lower than the water solubility value at the experimental pressure. The only exception is charge 4-1 (Table 1) which contains about 1 wt $\%$ fluid. Calculated fluid phase compositions are all carbonic, with wt $\% \mathrm{CO}_{2}$ ranging between 95 and $70\left(5-30 \mathrm{wt} \% \mathrm{H}_{2} \mathrm{O}\right)$. In glasses from run \#4 and \#5, $\mathrm{H}_{2} \mathrm{O}$ concentrations determined by FTIR are in general agreement with estimates using the by-difference method (Table 1), with the exception of two run products (5-1 and 5-2). With the progressive addition of calcite, $\mathrm{H}_{2} \mathrm{O}$ concentration decreases and $\mathrm{CO}_{2}$ concentration increases. This increase in dissolved $\mathrm{CO}_{2}$ with calcite addition probably reflects the combined influence of the enhanced 
$\mathrm{CO}_{2}$ fugacity in the fluid phase and of the progressive change of the melt composition toward higher $\mathrm{CaO}$ contents (Table 1). Thibault and Holloway (1994) have shown that, for a Ca-rich leucititic composition, $\mathrm{CO}_{2}$ solubilities are substantially higher than for MORB compositions (Pan et al. 1991; Dixon et al. 1995). Melts from charges 4-4, 5-4 and 5-5 (Table 1) are characterized by $\mathrm{CaO}$ contents well exceeding $15 \mathrm{wt} \%$ (Table 1). However, such extreme compositions are not representative of the less calcic melts from the other experiments (\#3, $\# 6$, \#7 and \#8), which are believed to contain much lower $\mathrm{CO}_{2}$ contents (on average $0.2 \mathrm{wt} \%$ ).

\subsection{Carbonate assimilation: influence on phase relations}

The effect of carbonate assimilation is essentially the same for both studied compositions. In all experiments, carbonate completely breakdowns, calcium and magnesium are incorporated in silicates (crystal + melt), while $\mathrm{CO}_{2}$ is partitioned between the fluid phase and the silicate glass, with a strong preference for the fluid. No newly formed carbonate phase (such as an immiscible carbonate melt) has been observed. With increasing carbonate addition the degree of crystallization of the magma increases (Table 1-2; Fig.1) and clinopyroxene (Cpx) becomes the dominant crystallizing phase. At given experimental conditions $\left(\mathrm{P}, \mathrm{T}\right.$, wt $\% \mathrm{H}_{2} \mathrm{O}$, wt $\%$ carbonate), composition PST9 always crystallizes significantly more Cpx than composition ST18, probably owing to its higher initial $\mathrm{CaO}$ content. All the other phases that are stable in calcite-free samples (plagioclase and Fe-Ti oxides at $1 \mathrm{~atm}$; olivine, plagioclase and Fe-Ti oxides at $200 \mathrm{MPa}$; amphibole and phlogopite at $500 \mathrm{MPa}$ ) progressively disappear as the amount of added calcite increases (Table 1-2; Fig.1). For $>10 \mathrm{wt} \%$ carbonate addition, Cpx is nearly the only crystallizing phase at any pressure and temperature. At low temperature $\left(1050^{\circ} \mathrm{C}\right)$ and $\sim 200 \mathrm{MPa}$, runs with calcite contents $>9 \mathrm{wt} \%$ show also traces of wollastonite and apatite (Table 1,2 and 4).

The olivine-added experiments (runs \#7 and \#8) provide further evidence on the behavior of olivine in presence of progressively increasing amounts of calcite. In these runs, the calcitefree charges are all olivine-saturated. Olivine may be accompanied by cpx and plagioclase depending on temperature and starting composition (Tables 1-2). With the progressive addition of calcite, the proportion of olivine and plagioclase present progressively decreases (Tables 1, 2; Fig. 1), and olivine disappears as a crystallizing phase for proportions of added calcite between 9 and $17 \mathrm{wt} \%$. The net effect of calcite addition is, therefore, to remove magnesian olivine from the liquidus, clinopyroxene becoming the liquidus phase for basaltic magmas having assimilated $\sim 15 \mathrm{wt} \%$ calcite. 


\subsection{Carbonate assimilation: compositional effects}

The composition of pyroxene that crystallizes in our experiments (Wol.: 44-50\%; En.: 30$42 \%$; Fs.: $7-30 \%$ ) is very sensitive to carbonate addition. Globally, the composition of clinopyroxene becomes richer in $\mathrm{CaO}$ as calcite is added in the charge (Table 3). As the amount of added calcite increases from 0 to $\sim 20 \mathrm{wt} \%$, the $\mathrm{CaO}$ content in the $\mathrm{Cpx}$ varies from 21 to $24 \mathrm{wt} \%$, reaching $25 \mathrm{wt} \%$ in weakly crystallized samples (run \#4 and \#5). Along with this increase in $\mathrm{CaO}$ content, the $\mathrm{Al}_{2} \mathrm{O}_{3}$ content systematically increases, whereas the $\mathrm{SiO}_{2}$ content decreases (Table 3). Silica partitioning between $\mathrm{Cpx}$ and liquid is sensitive to temperature: at low $\mathrm{T}\left(1050^{\circ} \mathrm{C}\right)$, the $\mathrm{SiO}_{2}$ content of the $\mathrm{Cpx}$ is lower than that of the liquid, while at high $\mathrm{T}\left(1100-1150^{\circ} \mathrm{C}\right)$, both are nearly equal. Therefore, Cpx crystallization increases the silica content of the residual liquid at low $\mathrm{T}$ and leaves it almost unaffected at high $\mathrm{T}$. The olivine composition is not greatly influenced by the amount of calcite addition: the $\mathrm{CaO}$ content remains below $0.5 \mathrm{wt} \%$, while the $\mathrm{MgO}$ content slightly increases with calcite addition (Table 4).

The chemical composition of the residual liquid is greatly affected by calcite incorporation. In samples from runs $\# 4$ and $\# 5$, the addition of $\mathrm{CaCO}_{3}$ results in a significant increase in the $\mathrm{CaO}$ content of the liquid. This is because the degree of crystallization remains low in these charges owing to their relatively high water content (Table 1). On the contrary, in charges from the other runs, most of the calcium coming from the breakdown of calcite is accommodated by Cpx crystallization. With no olivine added (runs \#1, \#2, \#3, \#6), a slight $\mathrm{CaO}$ enrichment in the residual liquid (and the appearance of trace amounts of wollastonite) is observed for samples with more than $10 \mathrm{wt} \%$ calcite (Table 1, 2). When olivine is added (runs \#7 and \#8), higher amounts of calcite (up to $17 \mathrm{wt} \%$ ) can be assimilated without a substantial increase in the $\mathrm{CaO}$ content of the melt (Table 1,2): the resulting increase in the bulk $\mathrm{CaO}$ content is accommodated by further crystallization of $\mathrm{Cpx}$. In addition to $\mathrm{CaO}$, concentrations of other major oxides in residual melts show large variations with the progressive addition of carbonate, these latter being directly linked to, and controlled by, Cpx crystallization. A strong "passive" enrichment in alkalis is observed, due to the enhanced Cpx crystallization with carbonate addition. Alkalis do not enter Cpx composition and are therefore significantly enriched in the melt. Both $\mathrm{SiO}_{2}$ and $\mathrm{MgO}$ usually decrease and $\mathrm{Al}_{2} \mathrm{O}_{3}$ slightly increases when progressively higher amounts of calcite are assimilated at constant temperature (Table 1, 2), although the decrease in $\mathrm{MgO}$ with calcite addition is less marked in olivine-added charges. 
The evolution with temperature of the residual liquid in absence and in presence of carbonates is illustrated in Figure 2, where the melt compositions obtained at $200 \mathrm{MPa}$ are plotted in a TAS (Total Alkali vs. Silica) diagram. If the proportion of carbonates assimilated is progressively increased at constant temperature, the silica content of the residual liquid decreases (desilication trends indicated by the arrows in Fig. 2). Figure $3 b$ shows how, in all calcite-free runs, residual liquids become substantially enriched in silica and, to a lesser extent, in alkali: when crystallization proceeds in absence of carbonate, residual melts have trachytic composition. If calcite is added, the alkali enrichment of the residual liquid becomes progressively more pronounced while the silica enrichment is less marked (Fig. 3b): when crystallization proceeds in presence of carbonates, residual liquids have phonolitic compositions (Fig. 3b).

\section{Discussion}

Conversely to what has been described in simple silicate systems such as the albite- $\mathrm{CaCO}_{3}$ $\mathrm{H}_{2} \mathrm{O}$ one (Watkinson and Wyllie 1969; Wyllie 1974), calcite can be massively incorporated in a mafic hydrous magma.

The two basaltic systems that were used in our experiments responded in a very consistent way to the addition of calcite, despite differences in major element compositions (e.g. $\mathrm{K}_{2} \mathrm{O} / \mathrm{Na}_{2} \mathrm{O}$ ). The observed differentiation trends typically lack silica-enrichment and are marked by silica-depletion if amounts of carbonates higher than $14 \mathrm{wt} \%$ are assimilated (Fig. 2-3). Although most of the critical evidence for carbonate assimilation comes from experiments performed at $200 \mathrm{MPa}$ with 2-3wt \% water, carbonate assimilation was also observed both at $1 \mathrm{~atm}$ in absence of water and at higher pressure (500 $\mathrm{MPa})$ under water rich conditions (6 $\mathrm{wt} \%)$. In both cases, carbonate interaction has essentially the same effects, with slightly lower intensity, as documented at $200 \mathrm{MPa}$ with 2-3wt\% water: the melt undergoes a strong alkali-enrichment at progressively decreasing silica content (Table 2, Fig. 3). Therefore, the carbonate reaction mechanism appears to be essentially the same whatever the experimental conditions and the composition of the starting material. Below, we focus on the characteristics of the carbonate assimilation mechanism.

The major effects of calcite assimilation, illustrated by our experiments, are the enhancement of Cpx crystallization, the progressive desilication of the residual melt with increasing carbonate content and the strong enrichment in alkali. The entire process is controlled by the amount of Cpx that crystallizes in response to calcite assimilation. Because olivine reacts out 
during this process (Fig. 1), Cpx is the most Mg-rich crystalline phase produced as a result of carbonate assimilation. Therefore, the extent of the assimilation process is controlled by the amount of $\mathrm{MgO}$ available in the magma (Barnes et al., 2005). Different cases may be distinguished, depending on the availability and concentration of $\mathrm{MgO}$ in the bulk magmatic system. In an olivine-saturated basaltic system, the calcite assimilation process, according to our experiments (run \#7 and \#8), can be written schematically as:

$2 \mathrm{CaCO}_{3}+3 \mathrm{SiO}_{2}{ }^{\text {melt }}+\mathrm{Mg}_{2} \mathrm{SiO}_{4}{ }^{\text {olivine }} \rightarrow 2 \mathrm{CaMgSi}_{2} \mathrm{O}_{6}{ }^{\mathrm{cpx}}+2 \mathrm{CO}_{2}{ }^{\text {fluid }}$

This destabilization of olivine in favor of Cpx with progressive carbonate assimilation has been described in petrological studies (Barnes et al. 2005 and references therein). In the case of a magma that is not olivine saturated (run \#6), the calcite assimilation mechanism can be written as:

$\mathrm{CaCO}_{3}+\mathrm{MgO}^{\text {melt }}+2 \mathrm{SiO}_{2}{ }^{\text {melt }} \rightarrow \mathrm{CaMgSi}_{2} \mathrm{O}_{6}{ }^{\mathrm{cpx}}+\mathrm{CO}_{2}{ }^{\text {fluid }}$

Reaction (1) and (2) implies that the extent of calcite assimilation is principally controlled by the $\mathrm{MgO}$ content of the bulk magma (olivine plus melt). Mechanism (2) leads to a faster depletion in the $\mathrm{MgO}$ content of the residual melt than mechanism (1). Indeed, experiments with no olivine added show a much stronger decrease in the $\mathrm{MgO}$ content of the liquid than the olivine-added ones (Table 1,2). However, it should be pointed out that natural carbonates may comprise an important fraction of dolomitic component, thus providing an additional source of $\mathrm{MgO}$ to be considered in the assimilation chemical budget.

Both reactions (1) and (2) imply that calcite incorporation in the magma will consume the $\mathrm{SiO}_{2}{ }^{\text {melt }}$ component to form $\mathrm{Cpx}$. The net result of this process will be a progressive lowering of the silica content of the melt (desilication) with assimilation of progressively higher amounts of carbonate, as observed in our experiments. Figure 4 illustrates how the degree of silica saturation of the residual liquid ( $\Delta \mathrm{Q}$, after Peccerillo 2005a) decreases with carbonate addition. The $\mathrm{MgO}$ content of the assimilating basalt (olivine + melt) plays an important role in this process: the higher the initial $\mathrm{MgO}$ content, the more pronounced the silica depletion of the residual melt for a given amount of carbonate added because a higher proportion of Cpx crystallizes.

If olivine is absent and the $\mathrm{MgO}$ melt component is not high enough to crystallize $\mathrm{Cpx}$, or in the case of a system under-saturated with respect to $\mathrm{Cpx}$, then calcite will initially dissolve as: $\mathrm{CaCO}_{3} \rightarrow \mathrm{CaO}^{\text {melt }}+\mathrm{CO}_{2}^{\text {fluid }}$

leading to the formation of calcium-rich liquids. This process is clearly revealed by runs \# 4 and \#5 in which the $\mathrm{CaO}$ content in the residual liquid reaches values as high as $\sim 20 \mathrm{wt} \%$. Mechanism (3) leads to melts with $\mathrm{CaO} / \mathrm{Al}_{2} \mathrm{O}_{3}>1$ (charges 4-4, 5-5, Table 1) at relatively 
elevated MgO concentrations (i.e., 6-7 wt\%). Danyushevsky et al. (2004) have stressed the common presence of $\mathrm{CaO}$-rich melt inclusion compositions in subduction-related lavas. Such compositions have also been found at Mt. Etna and Mt. Vesuvius (Kamenetsky and Clocchiatti 1996; Marianelli personal communication). Calcite assimilation was suggested as one of the possible mechanisms responsible for the generation of these anomalous compositions (Danyushevsky et al. 2004). Our results thus provide an experimental confirmation of this process. Note that, in this case also, the silica-saturation index of the residual liquid decreases with carbonate addition, because of a dilution effect that arises from the increase in the melt $\mathrm{CaO}$ content. The energetic cost of mechanisms (1) and (2) is much less than that of mechanism (3). At $1200 \mathrm{~K}$, the enthalpy changes associated with reaction (1) and (3) are $64 \mathrm{~kJ} / \mathrm{mol}$ and $166 \mathrm{~kJ} / \mathrm{mol}$ respectively (Robie et al. 1978). In nature, olivinesaturated magmas are the hottest, therefore favoring chemical exchanges with wall-rocks. Hence, reaction (1) probably represents the most common and efficient mechanism of carbonate assimilation in nature. Note that, during magma evolution, carbonate assimilation will become less efficient, because of cooling and decreasing $\mathrm{MgO}$ content of the melt (Barnes et al. 2005).

It is important to stress that, for the two basaltic systems studied in this paper, large amounts of carbonate (up to $\sim 20 \mathrm{wt} \%$ ) were assimilated according to mechanisms (1) and (2). The melt fraction was kept at values above $23 \%$ and desilication of the melt was systematically found. In contrast, the experiments of Watkinson and Wyllie (1969) were performed on hydrous albitic systems (i.e. magnesium-free), and the carbonate assimilation mechanism is notably different from those identified here, being dominated by massive plagioclase crystallization as a result of the progressive addition of $\mathrm{CO}_{2}$ to the system. Limited desilication of the melt was observed and complete solidification occurred for $\sim 25 \mathrm{wt} \%$ of calcite added. Their experiments are applicable to the assimilation of carbonate by relatively low-temperature hydrous felsic magmas but we show here that other mechanisms need to be considered in the case of higher-temperature, magnesian magmas such as basalts.

As illustrated in reactions (1), (2) and (3), carbonate assimilation systematically liberates large quantities of $\mathrm{CO}_{2}$ gas. For our experimental pressures, the $\mathrm{CO}_{2}$ liberated during calcite assimilation cannot completely dissolve in the melt because its solubility does not exceed 0.3 and $0.6 \mathrm{wt} \% \mathrm{CO}_{2}$ in calcic and hypercalcic melts respectively (Table 1, see also Dixon et al. 1995; Thibault and Holloway 1994). This explains the presence of a $\mathrm{CO}_{2}$-rich fluid phase in our experiments (up to $9 \mathrm{wt} \%$, Table 1, 2). In natural systems, the liberation of important amounts of $\mathrm{CO}_{2}$ as a result of carbonate assimilation may promote the formation of a free 
fluid phase at depth. This will cause a redistribution of components between melt and fluid (run \#4 and \#5 suggest that calcite addition drains water out of the melt, Table 1). Depending on the porosity of the wall rocks, this fluid phase may coexist with the magma or rapidly separate from it. If coexisting with the magma, its presence would undoubtedly affect the degassing behavior of the magma (Iacono Marziano et al. 2007) and both its density and viscosity: Assimilation of $9 \mathrm{wt} \%$ carbonate would liberate a $\mathrm{CO} 2$-rich fluid $\left(90 \% \mathrm{CO}_{2}\right.$ and $10 \% \mathrm{H}_{2} \mathrm{O}$ ) increasing by $20 \%$ the volume of the magma at $200 \mathrm{MPa}$ and $1150^{\circ} \mathrm{C}$. Ultimately, whenever the $\mathrm{CO}_{2}$-rich fluids produced by limestone assimilation are dissipated through the fault system of the surrounding rocks, $\mathrm{CO}_{2}$ emissions in volcanic areas (soil diffuse degassing, $\mathrm{CO}_{2}$ content in groundwaters, plume degassing) must be affected (Iacono Marziano et al. 2007).

\section{Italian quaternary volcanoes as a case study}

\subsection{General}

Central-Southern Italy is a volcanic region active since 1 million years (Peccerillo 2005a) and currently characterized by massive $\mathrm{CO}_{2}$ diffuse degassing of debated origin (Chiodini et al. 2001; 2004). Italian volcanoes are emplaced on sedimentary sequences mostly composed of carbonate rocks, whose thickness often exceed 5 km (Barberi et al. 1994; Peccerillo 1998; 2005; Mazzotti et al. 2000; Neri et al. 2005). Magma reservoirs are located in or at the base of the sedimentary pile (Barberi et al. 1994; Chiarabba et al. 1997; Auger et al. 2001; Aloisi et al. 2002). Intense interactions between the magma and the host carbonate rocks are documented by numerous metamorphosed carbonate and high temperature skarn xenoliths commonly occurring in volcanic products of the Campanian, Roman, Intra-Apennine Provinces and at Mt. Etna (Joron et al. 1987; Federico et al. 1994; Nappi et al. 1995; Michaud 1995; Peccerillo 1998; 2005; Gilg et al. 2001; Fulignati et al. 2000; Del Moro et al. 2001; Di Battistini et al. 2001).

From South to North, the K/Na ratio of Italian volcanic products generally increases yielding ultrapotassic lavas in the northernmost part (Tuscan Province and Intra-Apenninic centers, Fig.5, after Peccerillo 2005a). Potassium-enriched magmas have been interpreted to derive from variably metasomatised phlogopite-rich mantle (Conticelli and Peccerillo 1992). Complex trace elements and isotope trends have also been largely recognized and explained in terms of both contamination of the mantle source by entrainment of upper crust material in 
the subduction process and contamination during magma transfer and storage within the crust (Dallai et al. 2004; Civetta et al. 2004; Peccerillo 2005a). However, this scenario is not unanimously accepted and an intra-continental, passive rifting is also defended by some authors (Lavecchia and Stoppa 1996).

Both quartz-normative and strongly silica-undersaturated magma can be emitted at the same volcanic center and such changes in the degree of silica-saturation are uncorrelated with the variations of the $\mathrm{K} / \mathrm{Na}$ ratio (Fig. 5; after Peccerillo 2005a). These changes in the degree of silica-saturation do not correlate with any significant change in the isotopic composition (Ayuso et al. 1998; Peccerillo 2005a; Di Renzo et al. 2007; Frezzotti et al. 2007). For instance, Mts. Vulsini (Roman Province) and Mt. Vesuvius (Campanian Province) show large changes in their degree of silica-saturation (Fig.5), without any clear isotopic indication suggesting a variation of the composition of the source (Ayuso et al. 1998; Peccerillo 2005a; Di Renzo et al. 2007). Although several mechanisms have already been proposed to explain such variations in the degree of silica-saturation (variable pressures, degrees of partial melting and $\mathrm{H}_{2} \mathrm{O} / \mathrm{CO}_{2}$ ratio of the mantle source; see Panza et al. 2007 and references therein), our experimental results indicate that carbonate assimilation at shallow level is an additional mechanism that can account for the changes in silica-saturation observed in these volcanic areas. Indeed, carbonate assimilation described in our experiments has a negligible influence on the $\mathrm{K}_{2} \mathrm{O} / \mathrm{Na}_{2} \mathrm{O}$ ratio of the magma (Table 1-2; Fig.5), which is probably inherited from the melting conditions in the mantle. On the contrary, carbonate assimilation deeply affects the degree of silica-saturation of the concerned magmas, consistent with the substantial variations in $\Delta \mathrm{Q}$ observed in the eruptive products of a single volcanic center (Fig.4-5). Expected variations in the $\mathrm{Sr}$ isotopic signature of magma resulting from different amounts of carbonate assimilation are relatively small for most Italian volcanoes as we show in detail for Mt. Vesuvius (see section 5.2 and Fig.7). Indeed, sedimentary carbonates, which are strongly depleted in trace elements and isotopes, leave a very slight fingerprint in the magma; particularly in the case of Central-Southern Italian magmas, which have high radiogenic strontium content and high LILE contents, elements that are classically used to quantify assimilation (Del Moro et al. 2001; Fulignati et al. 2004; Civetta et al. 2004; Peccerillo 2005a; Piochi et al. 2006; Di Renzo et al. 2007).

Clearer geochemical signatures of carbonate assimilation come from oxygen isotopic studies, due to the strong enrichment in ${ }^{18} \mathrm{O}$ of carbonate rocks $\left(\delta^{18} \mathrm{O}=25-28 \%\right.$; Turi, 1970). $\delta^{18} \mathrm{O}$ measurements in clinopyroxenes from the Alban Hills and Mt. Vesuvius present values up to $8.33 \%$ and $7.30 \%$ respectively, which are substantially higher than in mantle rocks (Dallai et 
al. 2004; 2007). These values approach the ones measured in Cpx from thermometamorphic ejecta in the Alban Hills area $(8.4 \pm 0.20 \%$ ) and most likely reveal magma contamination by sedimentary carbonates (Dallai et al. 2004; 2007). The highest oxygen isotope values have been measured in the Intra-Apennine ultrapotassic volcanic rocks (kamafugites) and in the associated carbonate-rich rocks (Stoppa and Woolley 1997; Peccerillo 1998). $\delta^{18} \mathrm{O}$ values in the kamafugites are in the range 11.9-14.4 \%o (Holm and Munskgaard 1982; Taylor et al. 1984), while in the carbonate-rich rocks are 21.1-25.4, very similar to the one of limestone (Stoppa and Woolley 1997) and very different from the one of mantle-derived carbonatite (Hoefs 1987). The strong silica-undersaturated nature of the kamafugites (Fig. 5) corroborates the conclusion of Peccerillo (1998) that these magmas probably assimilated ca. $20 \mathrm{wt} \%$ of carbonate even if other mechanisms cannot be excluded (Stoppa and Woolley 1997; see discussion in Peccerillo 2005a).

Hereafter, we focus on Mt. Vesuvius and we describe in detail the trends in major and trace element compositions of its eruptive products, summarized in Table 5, which result to be consistent with the petrological mechanisms of carbonate assimilation identified in our experiments.

\subsection{Mt. Vesuvius}

Mt. Vesuvius eruptive products are characterized by important temporal variations in the degree of silica-saturation. In the last $25 \mathrm{ka}$, three periods/eruptive cycles have been recognized (Joron et al. 1987; Ayuso et al. 1998): the younger the lavas, the more silicaundersaturated (Fig 3a). Comparison between Figures $3 \mathrm{a}$ and $3 \mathrm{~b}$ suggests that the evolution from slightly (Period I: 25-14 ka) to strongly (Period III: 79 AD-recent) silica-undersaturated compositions is consistent with a progressively increasing degree of carbonate assimilation. In this respect, it is worth noting that the decrease in the silica content of the most primitive rocks $(\mathrm{MgO}>6 \mathrm{wt} \%)$ from Period I to Period III $\left(\mathrm{SiO}_{2}\right.$ from 50 to $47 \mathrm{wt} \%$, on average) is balanced by an increase in the $\mathrm{CaO}$ content (from 8-9 to $11-13 \mathrm{wt} \%$ ), the other chemical elements being otherwise unchanged (data available in Joron et al. 1987 and Ayuso et al. 1998). Such increase in the degree of carbonate assimilation with time would be consistent with the nearly continuous injection of hot magma during the last $25 \mathrm{ka}$, which would have resulted in an increase in the temperature of the carbonate wall-rocks (Civetta et al. 2004).

Further evidence of increasing carbonate assimilation with time comes from mineral parageneses. Slightly silica undersaturated rocks (shoshonitic compositions, mainly belonging 
to Period I) typically show plagioclase and olivine as major phases, whereas strongly undersaturated rocks (phonotephritic compositions, mainly belonging to Period III) do contain essentially Cpx with rare plagioclase and olivine (Joron et al. 1987; Piochi et al. 2006; Di Renzo et al. 2007). Furthermore, near-liquidus experimental phase assemblages for primitive (7-8 $\mathrm{wt} \% \mathrm{MgO}) \mathrm{Mt}$. Vesuvius lavas from the recent period typically lack olivine (Pichavant et al. in progress). This is consistent with the change in phase equilibria documented in our experiments: plagioclase and olivine are destabilized as carbonate is added to the magma. The progressive disappearance of plagioclase from the mineral assemblage explains the change in Sr behavior from compatible to incompatible between rocks of Period I and III (Peccerillo 2005b). Indeed, plagioclase concentrates 3000-5000 ppm of strontium (Joron et al., 1987; Civetta et al. 1991) and therefore strongly depletes in Sr the coexisting melt. In contrast, clinopyroxene contains less than 300 ppm Sr (Civetta et al. 1991; Del Moro et al 2001; Piochi et al. 2006) and its crystallization enriches the residual melt in Sr (see Fig. 6.6 in Peccerillo 2005b). The Europium anomaly, relatively well marked in the ancient rocks of Period I, disappears in the more recent products (Ayuso et al. 1998), clearly marking the destabilization of plagioclase from the early crystallizing assemblage.

Compositions of primitive $(\mathrm{MgO}>6 \mathrm{wt} \%)$ melt inclusions from the Period II (Avellino, 3400 BP, Cioni et al 1998) and III (AD 79, AD 472 and recent, Cioni et al 1998; Cioni 2000; Fulignati et al. 2004; Marianelli et al. 1995, 2005) are shown in Figure 6. These melt inclusions were interpreted by the authors as entrapped at shallow level, most likely in the sedimentary carbonate. Their $\mathrm{MgO}$ contents are $>8 \mathrm{wt} \%$ in the silica-rich, alkali-poor region, and decrease down to $6 \mathrm{wt} \%$ with decreasing silica content. This suggests that, with progressive magma evolution and fractionation, liquids evolve towards silica-poorer and alkali-richer compositions (Fig. 6a). This evolution is accompanied by a continuous progressive increase in $\mathrm{CaO} / \mathrm{MgO}$ (Fig. 6b). Such chemical trends cannot be explained by crystal fractionation alone, because they would require the massive crystallization of a strongly silica-rich phase which does not exist at Mt. Vesuvius. The olivine-doped experiments at $1150^{\circ} \mathrm{C}$ (with melt $\mathrm{MgO}>6 \mathrm{wt} \%$ ) remarkably plot on the trend drawn by the melt inclusions on Figure 67a,b. This strongly suggests that the inclusion chemical trend is controlled by the assimilation mechanism (1), and indicates degrees of assimilation up to 15$17 \mathrm{wt} \%$ of limestone in the Period III (1794-1944). In detail, degrees of assimilation recorded by the magmatic inclusions appear to vary for a single eruptive period, but the inclusions from the Avellino eruption (Period II) are, on average, more silicic than inclusions from the Period III (Fig. 6), again suggesting an increasing degree of carbonate assimilation with time. Glass 
inclusions in high temperature skarns $(\mathrm{MgO}=3-4.5 \mathrm{wt} \%$; Fulignati et al. 2004) extend the trend toward higher alkali (Fig. 6a), $\mathrm{CaO} / \mathrm{MgO}$ (Fig. 6b) and lower silica contents. This suggests that the same evolutionary mechanism (1) still applies, and indicates proportions of assimilated carbonates $>17 \mathrm{wt} \%$ at the contact with the wall-rock, where the high temperature skarns are formed. It is important to retain that the contamination process essentially occurs during the early magmatic stages, when the magma has $\mathrm{T}>1100^{\circ} \mathrm{C}$ and $\mathrm{MgO}$ content of $10-5 \mathrm{wt} \%$. At lower temperatures and $\mathrm{MgO}$ contents, assimilation can still occur, but it is partial, as evidenced by skarn assemblages, and it probably remains a more localized process (as observed by Del Moro et al. 2001 and Fulignati et al. 2004).

Hereafter, we test the carbonate assimilation mechanism for the primitive melts of the most recent eruptions (1794-1944), in terms of $\mathrm{Sr}$ variations. We consider a shoshonite $\left(\mathrm{SiO}_{2} \sim 52\right.$ $\mathrm{wt} \%$; $\mathrm{MgO} \sim 8-9 \mathrm{wt} \%)$ that differentiates into a tephrite $\left(\mathrm{SiO}_{2} \sim 48 \mathrm{wt} \% ; \mathrm{MgO} \sim 5-6 \mathrm{wt} \%\right)$. According to our experimental results, the assimilation-differentiation process can be summarized as:

SHOSHONITE $+\mathrm{CaCO}_{3}=>$ TEPHRITE $+\mathrm{Cpx}+\mathrm{CO}_{2}$

Unfortunately, the $\mathrm{Sr}$ isotopic ratio in shoshonitic melt inclusions is unknown. Typical bulk rock ${ }^{87} \mathrm{Sr} /{ }^{86} \mathrm{Sr}$ values and $\mathrm{Sr}$ concentrations for Mt. Vesuvius shoshonites are respectively ca. 0.7067 and 737 ppm (Fig. 7; Di Renzo et al. 2007). These shoshonites are considered as one of the least differentiated compositions at Mt. Vesuvius (Di Renzo et al. 2007), but their MgO content $(\sim 6 \mathrm{wt} \%)$ suggests that they have already suffered from olivine fractionation. Lower $\mathrm{Sr}$ contents are therefore likely for more primitive magmas having $\mathrm{MgO}=8-9 \mathrm{wt} \%$. Figure 7 shows the expected trends from mechanism (4) in a plot ${ }^{87} \mathrm{Sr} /{ }^{86} \mathrm{Sr}$ vs. bulk Sr. Two types of limestone have been considered, given that the Sr content of Campanian carbonates is thought to vary between 500 and $1000 \mathrm{ppm}$ and its isotopic ratio between 0.7075 and 0.709 (Piochi et al. 2006 and references therein; Di Renzo et al. 2007): limestone L1 $\left(\mathrm{Sr}=500 \mathrm{ppm} ;{ }^{87} \mathrm{Sr} /{ }^{86} \mathrm{Sr}=\right.$ $0.708)$ and limestone $\mathrm{L} 2\left(\mathrm{Sr}=1000 \mathrm{ppm} ;{ }^{87} \mathrm{Sr} /{ }^{86} \mathrm{Sr}=0.709\right)$. Mixing curves between the shoshonite (SHO) and the two types of limestone are shown: in both cases, limestone assimilation increases the strontium isotopic ratio of the shoshonite. Typical values for the recent 1944 phonotephrites (PTph 1944) are Sr= $1312 \mathrm{ppm} ;{ }^{87} \mathrm{Sr} /{ }^{86} \mathrm{Sr}=0.707191$ (Del Moro et al. 2001; Civetta et al. 2004). Cognate cumulates (clinopyroxenite, CPX 1944) have similar isotope ratios, but much lower strontium concentrations (respectively 0.70729,<200 ppm; Del Moro et al. 2001; Piochi et al. 2005). A combination of the two end members in proportions 35-50 wt \% Cpx and 50-65 wt \% phonotephritic melt is reproduced by an assimilation of 45-50 $w t \%$ of limestone $\mathrm{L} 1$ or $15-20 \mathrm{wt} \%$ of limestone $\mathrm{L} 2$. The type of limestone, i.e. values of $\mathrm{Sr}$ 
concentrations and isotopic compositions of the assimilated carbonate rocks, crucially affect this kind of calculation. Although a quantitative estimate of the degree of assimilation via this method needs more accurate measurements of $\mathrm{Sr}$ concentrations and isotopic signature of both primary magmas and carbonate rocks, the mechanism (4) appears to bridge the gap between the Sr radiogenic composition of older shoshonites and the one of recently erupted phono-tephrites. To better visualize the effect of reaction (4) in Figure 7, we plotted the theoretical position of experiments \#7-4 to \#7-6 and \#8-4 to \#8-6. Their Sr concentration and isotopic composition was calculated by mass balance, considering SHO and L2 as initial component, their percentage and the resulting phase proportions (olivine $+\mathrm{Cpx}+$ melt). This representation shows both the enrichment in strontium and the increases in its isotopic ratio consequent to 8-9 and 15-17 wt\% of limestone L2 assimilation. Mechanism (4) reproduces major element trends and can potentially explain the variation in strontium concentration and isotope ratio between Shoshonite and Phonotephrite. This conclusion corroborates recent results obtained using AFC modelling by Di Renzo et al. (2007), who concluded that Sr and $\mathrm{Nd}$ variations between Mt. Vesuvius shoshonites and phonotephrites can be accounted for by $14 \mathrm{wt} \%$ of limestone assimilation accompanied by $38 \%$ crystallization.

\section{Conclusions and outlooks}

Previously discarded on the basis of experimental and geochemical constraints, limestone assimilation by basaltic magma is here demonstrated as a physically possible magmatic process. We characterized the petrological consequence of such assimilation, showing that it induces desilication of the residual liquid and leads to strongly silica-undersaturated melts. Similar desilication trends are recognized in the primitive melt inclusions of Mt. Vesuvius eruptive products, consistently with up to $15 \mathrm{wt} \%$ limestone assimilation. This process also accounts for observed minor variations in trace and isotope signatures that accompany clear changes in the degree of silica-undersaturation. In conclusion, increasing amounts of carbonate assimilation from Period I (25-14 ka) to Period III (79 AD-recent) may explain variations in bulk rock and melt inclusion compositions, mineral assemblages, $\mathrm{Sr}$ and $\mathrm{Eu}$ behavior during fractionation at Mt. Vesuvius (Table 5).

Iacono Marziano et al. (2007) have shown that also Alban Hills volcanic rocks have most likely undergone important degrees of carbonate assimilation. Limestone assimilation is probably a regional process occurring in the plumbing system of Italian volcanoes explaining the genesis of strongly silica-undersaturated rocks. This implies that important magmatic 
features of Italian volcanoes are probably not exclusively inherited from the mantle. Moreover, the large quantity of gaseous $\mathrm{CO}_{2}$ liberated during the carbonate assimilation process has certainly profound effect on the magma chamber dynamics and volatile transfers toward the surface that needs to be further investigated.

Acknowledgement: G.I.M. would like to acknowledge Daniela Dolfi for discussions and original point of views on the quaternary magmatism in Italy and the INGV of Palermo for the postdoctoral grant that permitted her to accomplish this study. G.I.M. and F.G. also benefited of postdoc grants on the Visitor program of the BGI (Prof. D. Rubie) that allowed this study to be initiated at BGI (Bayreuth). The work performed at ISTO (Orléans) was funded by the French ANR (grant \#JC 05-42707 to F.G.). This study benefited of helpful exchanges with Bruno Scaillet and Angelo Peccerillo.

\section{References:}

Aloisi M, Cocina O, Neri G, Orecchio B, Privitera E (2002) Seismic tomography of the crust underneath the Etna volcano, Sicily. Physics of the Earth and Planetary Interiors 4154: 1-17

Auger E, Gasparini P, Virieux J, Zollo A (2001) Seismic evidence of an extended magmatic sill under Mt. Vesuvius. Science 294: 1510-1512

Ayuso RA, De Vivo B, Rolandi G, Seal RR, Paone A (1998) Geochemical and isotopic (Nd$\mathrm{Pb}-\mathrm{Sr}-\mathrm{O}$ ) variations bearing on the genesis of volcanic rocks from Vesuvius, Italy. $\mathrm{J}$ Volcanol Geotherm Res 82: 53-78

Baker CK, Black PM (1980) Assimilation and metamorphism at a basalt-limestone contact, Tokatoka, New Zealand. Mineral Mag 43: 797- 807

Barberi F, Leoni L (1980) Metamorphic carbonate ejecta from Vesuvius plinian eruptions: evidence of the occurrence of shallow magma chamber. Bull Volcanol 43: 107-120

Barberi F, Buonasorte G, Cioni R, Fiordelisi A, Foresi L, Iaccarino S, Laurenzi M A, Sbrana A, Vernia L, Villa IM (1994) Plio-Pleistocene geological evolution of the geothermal area of Tuscany and Latium. Memorie Descrittive Carta Geologica d'Italia XLIX: 77-134

Barnes CG, Prestvik T, Sundvoll B, Surratt D (2005) Pervasive assimilation of carbonate and silicate rocks in the Hortavær igneous complex, north-central Norway. Lithos 80: 179-199

Bonardi G, Cavazza W, Perrone V, Rossi S (2001) Calabria-Peloritani terrane and northern Ionian Sea. In: Vai GB, Martini PI (eds) Anatomy of an orogen. The Apennines and the Adjoining Mediterranean Basins. Kluwer, Dordercht, 287-306

Buhn B, Trumbull RB (2003) Comparison of petrogenetic signatures between mantle-derived alkali silicate intrusives with and without associated carbonatite, Namibia. Lithos 66: 201221

Chiarabba C, Amato A, Delaney PT (1997) Crustal structure, evolution and volcanic unrest of the Alban Hills, Central Italy: Bull Volcanol 59: 161-170

Chiodini G, L. Marini, and M. Russo (2001) Geochemical evidence for the existence of hightemperature hydrothermal brines at Vesuvio volcano, Italy. Geochim Cosmochim Acta 65: $2129-2147$ 
Chiodini G, Cardellini C, Amato A, Boschi E, Caliro S, Frondini F, Ventura G (2004) Carbon dioxide Earth degassing and seismogenesis in central and southern Italy Geophys Res Lett 31 doi:10.1029/2004GL019480

Cioni R, Marianelli P, Santacroce R (1998) Thermal and compositional evolution of the shallow magma chambers of Vesuvius: Evidence from pyroxene phenocrysts and melt inclusions. J Geophys Res 103: 18277-18294

Cioni R (2000) Volatile content and degassing processes in the AD 79 magma chamber at Vesuvius (Italy). Contrib Mineral Petrol 140: 40-54

Civetta L, Galati R, Santacroce R (1991) Magma mixing and convective compositional layering within the Vesuvius magma chamber. Bull Volcanol 53: 287-300

Civetta L, D’Antonio M, de Lorenzo S, Di Renzo V, Gasparini P (2004) Thermal and geochemical constraints on the 'deep' magmatic structure of Mt. Vesuvius. J Volcanol Geotherm Res 133: 1-12

Conticelli S, Peccerillo A (1992) Petrology and geochemistry of potassic and ultrapotassic volcanism in central Italy: petrogenesis and inferences on the evolution of the mantle sources. Lithos 28: 221-240.

Coulson IM, Westphal M, Anderson RG, Kyser TK (2007) Concomitant skarn and syenitic magma evolution at the margins of the Zippa Mountain pluton. Mineral Petrol 90:199-221

Dallai L, Freda C, Gaeta M (2004) Oxygen isotope geochemistry of pyroclastic clinopyroxene monitors carbonate contributions to Roman-type ultrapotassic magmas. Contrib Mineral Petrol 148: 247-263

Dallai L, Boschi C, D'Oriano C, Cioni R (2007) Oxygene isotope composition of mafic magmas at Vesuvius. Geoitalia2007. Epitome.02.0433: 126

Daly RA (1910) Origin of the alkaline rocks. Geol Soc Am Bull 21: 87-118

Danyushevsky LV, Leslie RAJ, Crawford AJ, Durance P (2004) Melt inclusions in primitive olivine phenocrysts: the role of localized reaction processes in the origin of anomalous compositions. J Petrol 45: 2531-2553

Del Moro A, Fulignati P, Marianelli P, Sbrana A (2001) Magma contamination by direct wall rock interaction: constraints from xenoliths from the walls of a carbonate-hosted magma chamber (Vesuvius 1944 eruption). J Volcanol Geotherm Res 112: 15-24

Devine JD, Gardner JE, Brack HP, Layne GD, Rutherford MJ (1995) Comparison of microanalytical methods for estimating $\mathrm{H} 2 \mathrm{O}$ contents of silicic volcanic glasses. Am Mineral 80: 319-328

Di Battistini G, Montanini A, Vernia L, Venturelli G, Tonarini S (2001) Petrology of melilitebearing rocks from the Montefiascone Volcanic Complex (Roman Magmatic Province): new insights into the ultrapotassic volcanism of Central Italy. Lithos 59: 1-24

Di Carlo I, Pichavant M, Rotolo SG, Scaillet B (2005) Experimental crystallization of a highK arc basalt: The yellow pumice, Stromboli Volcano (Italy). J Petrol 47: 1317-1343

Di Renzo V, Di Vito MA, Arienzo I, Carandente A, Civetta L, D'antonio M, Giordano F, Orsi G, Tonarini S (2007) Magmatic History of Somma-Vesuvius on the Basis of New Geochemical and Isotopic Data from a Deep Borehole (Camaldoli della Torre). J Petrol 48: 753-784

Dixon JE, Stolper EM, Holloway JR (1995) An experimental study of water and carbon dioxide solubilities in mid-ocean ridge basaltic liquids. Part I: Calibration and solubility models. J Petrol 36: 1607-1631

Elkins-Tanton LT, Grove TL (2003) Evidence for deep melting of hydrous metasomatized mantle: Pliocene high-potassium magmas from the Sierra Nevadas. J Geophys Res 108 doi: $10.1029 / 2002 / J B 002168$ 
Federico M, Peccerillo A, Barbieri M, Wu TW (1994) Mineralogical and geochemical study of granular xenoliths from the Alban Hills volcano, Central Italy: bearing on evolutionary processes in potassic magma chambers. Contrib Mineral Petrol 115: 384- 401

Foley S (1992) Petrological characterization of the source components of potassic magmas: Geochemical and experimental constraints. Lithos 28: 187-204

Frezzotti ML, De Astis G, Dallai L, Ghezzo C (2007) Coexisting calc-alkaline and ultrapotassic magmatism at Monti Ernici, Mid Latina Valley (Latium, central Italy). Eur J Mineral 19: 479-497

Fulignati P, Marianelli P, Santacroce R, Sbrana A, (2000) The skarn shell of the 1944 Vesuvius magma chamber: Genesis and $\mathrm{P}-\mathrm{T}-\mathrm{X}$ conditions from melt and fluid inclusion data. Eur J Mineral 12: 1025-1039

Fulignati P, Marianelli P, Métrich N, Santacroce R, Sbrana A (2004) Towards a reconstruction of the magmatic feeding system of the 1944 eruption of Mt Vesuvius. J Volcanol Geotherm Res 133: 13-22

Gaillard F, Pichavant M, Scaillet B (2003) Experimental determination of activities of FeO and $\mathrm{Fe}_{2} \mathrm{O}_{3}$ components in hydrous silicic melts under oxidizing conditions. Geochim Cosmochim Acta 67: 4389-4409

Gilg HA, Lima A, Somma R, Ayuso RA, Belkin HE, De Vivo B (2001) Isotope geochemistry and fluid inclusion study of skarns from Vesuvius. Mineral Petrol 73: 145-176

Hoefs J (1987) Stable Isotope Geochemistry. Berlin: Springer

Holm PM, Munskgaard NC (1982) Evidence for mantle metasomatism: an oxygen and strontium isotope study of the Vulsinian district, central Italy. Earth Planet Sci Lett 60: 376388

Joron Jl, Metrich N, Rosi M, Santacroce R, Sbrana A (1987) Chemistry and petrography, In Santacroce, R (ed) "Somma-Vesuvius". Quaderni de la ricerca scientifica, CNR, Roma 8: 105-171

Iacono Marziano G, Gaillard F, Pichavant M Limestone assimilation and the origin of $\mathrm{CO}_{2}$ emissions at the Alban Hills (Central Italy): constraints from experimental petrology. J Volcanol Geotherm Res 166: 91-105

Kamenetsky V, Métrich N, Cioni R (1995) Potassic primary melts of Vulsini (Roman Province): evidence from mineralogy and melt inclusions. Contrib Mineral Petrol 120: 186196

Kamenetsky V, Clocchiatti R (1996) Primitive magmatism of Mt Etna: insights from mineralogy and melt inclusions. Earth Planet Sci Lett 142: 553-572

Lavecchia G, Stoppa F (1996) The tectonic significance of Italian magmatism: an alternative view to the popular interpretation. Terra Nova 8: 435-444

Marianelli P, Metrich N, Santacroce R, Sbrana A (1995) Mafic magma batches at Vesuvius: a glass inclusion approach to the modalities of feeding potassic strato-volcanoes. Contrib Mineral Petrol 120: 159-169

Marianelli P, Sbrana A, Metrich N, Cecchetti A (2005) The deep feeding system of Vesuvius involved in recent violent strombolian eruptions. Geophys Res Lett 32 doi:10.1029/ 2004GL021667

Mazzotti A, Stucchi E, Fradelizi GL, Zanzi L, Scandone P (2000) Seismic exploration in complex terrains: a processing experience in the Southern Apennines. Geophysics 65: 14021417

Michaud V (1995) Crustal xenoliths in recent hawaiites from Mount Etna, Italy: evidence for alkali exchanges during magma-wall rock interaction. Chemical Geol 122: 21- 42

Nappi G, Renzulli A, Santi P, Gillot PY (1995) Geological evolution and geochronology of the Vulsini Volcanic District (central Italy). Boll Soc Geol It 114: 599-613 
Neri M, Acocella V, Behncke B, Maiolino V, Ursino A, Velardita R (2005) Contrasting triggering mechanisms of the 2001 and 2002-2003 eruptions of Mount Etna (Italy). J Volcanol Geotherm Res 144: 235- 255

Pan V, Holloway JR, Hervig RL (1991) The pressure and. temperature dependence of carbon dioxide solubility in tholeiitic basalt melts. Geochim Cosmochim Acta 55: 1587-1595

Panza GF, Peccerillo A, Aoudia A, Farina B (2007) Geophysical and petrological modelling of the structure and composition of the crust and upper mantle in complex geodynamic settings: The Tyrrhenian Sea and surroundings. Earth Sci Rev 80: 1-46

Peccerillo A (1998) Relationships between ultrapotassic and carbonate-rich volcanic rocks in central Italy: petrogenetic and geodynamic implications. Lithos 43: 267-279

Peccerillo A (2001) Geochemical similarities between Vesuvius, Phlegraean Fields and Stromboli volcanoes: petrogenetic, geodynamic and volcanological implications. Mineral Petrol 73: 93-105

Peccerillo A (2005a) Plio-Quaternary Volcanism in Italy. Springer-Verlag Berlin Heidelberg

Peccerillo A (2005b) Modeling the magma plumbing system of active volcanoes: a petrological and geochemical perspective. Acta Volcanol 17: 43-52

Pichavant M, Martel C, Bourdier JL, Scaillet B (2002) Physical conditions, structure and dynamics of a zoned magma chamber: Mt. Pele'e (Martinique, Lesser Antilles arc). J Geophys Res 107, B5: 1-28

Piochi M, Ayuso RA, De Vivo B, Somma R (2006) Crustal contamination and crystal entrapment during polybaric magma evolution at Mt. Somma-Vesuvius volcano, Italy: Geochemical and Sr isotope evidence. Lithos 86: 303-329

Rittmann A (1933) Evolution and differentiation des Somma-Vesuv-magmas. Zeitsch Vulkanol 15

Robie R.A, Hemingway BS, Fisher JR (1978) Thermodynamic properties of minerals and related substances at $298.15 \mathrm{~K}$ and 1 bar (105 Pascals) pressure and at higher temperature. Geol Surv Bull 1452: 456

Roux J, Lefèvre A (1992) A fast-quench device for internally heated pressure vessels. Eur J Mineral 4: 279-281

Shand SJ (1945) The present status of Daly's hypothesis of the alkaline rocks. Am J Sci 23: 495-507

Sisson TW Grove TL (1993) Experimental investigations of the role of water in calc-alkaline differentiation and subduction zone magmatism. Contrib Mineral Petrol 113: 143-166

Stoppa F, Woolley AR (1997) The Italian carbonatites: field occurrence, petrology and regional significance. Mineral Petrol 59: 43-67

Taylor HP, Turi B, Cundari A (1984) 18-O/16-O and chemical relationships K-rich volcanic rocks from Australia, East Africa, Antarctica, and San Venanzo-Cupaello, Italy. Earth P1 Sci Lett 69: 263-276

Thibault Y, Holloway JR, (1994) Solubility of $\mathrm{CO}_{2}$ in a Ca-rich leucitite: effects of pressure, temperature, and oxygen fugacity. Contrib Mineral Petrol 116: 216-224

Thibault Y, Edgar AD, Lloyd FE (1992) Experimental investigation of melts from carbonated phlogopite lherzolite: implications for metasomatism in the continental lithospheric mantle. Am Mineral 77: 784-794

Turi B (1970). Carbon and oxygen isotopic composition of carbonates in limestone blocks and related geodes from the "Black Pozzolans" formation of the Alban Hills. Chemic Geol 5: $195-205$

Watkinson DH, Wyllie PJ (1969) Phase equilibrium studies bearing on the limestone assimilation hypotheses. Geol Soc Am Bull 80: 1565-1576 
Wenzel T, Baumgartner LP, Brügmann GE, Konnikov EG, Kislov EV, Orsoev DA. (2002) Partial melting and assimilation of dolomitic xenoliths by mafic magma: the Ioko-Dovyren intrusion (north Baikal region, Russia). J Petrol 43:2049-2074

Wyllie PJ (1974) Limestone assimilation, In "The Alkaline Rocks" H. Sorensen Ed. 459-473

\section{Figure Captions:}

Figure 1:

Phase proportions of selected experiments as a function of the amount of calcite added for both starting composition (ST18 and PST9). All phase proportions are expressed in wt\%. Different temperature conditions are shown. High-temperature results $\left(1100\right.$ and $\left.1150^{\circ} \mathrm{C}\right)$ represent olivine-added experiments, whereas the low temperature data $\left(1150^{\circ} \mathrm{C}\right)$ are from an olivine-free experiment. Note the enhancement in the crystallization rate (the melt field decreases) and the dominance of clinopyroxene over all the other crystallizing phases with calcite addition.

Figure 2:

Experimental residual liquids obtained at $200 \mathrm{MPa}$ are plotted in a TAS (Total Alkali vs. Silica) diagram. For clarity, other experimental liquids are not shown here but are plotted in figure $3 \mathrm{~b}$. Squares and diamonds respectively represent experiments done from PST9 and the ST18 starting materials. The different colors stand for: light gray $=1050^{\circ} \mathrm{C}$; dark gray $=$ $1100^{\circ} \mathrm{C}$ (olivine added); black $=1150^{\circ} \mathrm{C}$ (olivine added); white $=$ starting glasses. Gray triangles represent experimental runs with PST9 composition that contained higher water contents (run \#4 and 5). Fields regroup desilication trends by mechanisms 1, 2, 3 (see part 4 in the text). The arrows in the inset indicate the desilication effect of carbonate assimilation as opposed to the effect of olivine and Cpx crystallization in a closed system.

Figure 3:

a) Whole rock compositions of Mt. Vesuvius eruptive products plotted in a TAS diagram. Fields marked by I, II and III represent the 3 Periods indicated after Ayuso et al. (1998). I: 2514 ky; II: 8 ky-AD79; III: AD79 (Pompeii eruption)-1944 (last eruptive event). Note the increasing degree of silica-undersaturation of the erupted products from Period I to Period III. b) Experimental residual liquids plotted as a function of the different amount of added carbonates: diamonds $=$ carbonate-free; squares $=2-5 \quad \mathrm{wt} \%$ carbonates; circles $=8-14 \mathrm{wt} \%$ carbonates; triangles $=15-19 \mathrm{wt} \%$ carbonates. Full symbols represent experiments at 
$\sim 200 \mathrm{MPa}$, while open symbols correspond to the experiments at 1 atm or $500 \mathrm{MPa}$. Contours for each $200 \mathrm{MPa}$ series are shown to facilitate the understanding of the figure. "Near liquidus" points represent runs $\# 4$ and $\# 5$, which present very low crystal contents and therefore illustrate near liquidus conditions.

Figure 4:

Degree of silica-saturation of experimental residual liquids obtained at $200 \mathrm{MPa}$ $\left(\Delta \mathrm{Q}=\mathrm{Quartz}_{\text {norm}}-\right.$ Olivine $_{\text {norm}}-$ Leucite $_{\text {norm }}-$ Kalsilite $_{\text {norm}}-$ Nefeline $_{\text {norm }}$, calculated after Peccerillo, 2005a). Different initial MgO contents of the starting silicate mixture are shown in the legend. Mechanism (1) in the text is mainly illustrated by the olivine-doped experiments with $\sim 10$ $\mathrm{wt} \% \mathrm{MgO}$, while mechanism (2) and (3) are better exemplified by olivine-free experiments with 5.74 and $7.82 \mathrm{wt} \% \mathrm{MgO}$.

Figure 5:

Plot of $\mathrm{K} / \mathrm{Na}$ versus the degree of silica-saturation $(\Delta \mathrm{Q}$, calculated as in Fig. 4) of CentralSouthern Italian volcanic rocks with $\mathrm{MgO}>4 \mathrm{wt} \%$ (after Peccerillo 2005a). The influence of limestone assimilation on $\Delta \mathrm{Q}$, deduced from our experimental results (see Fig. 4), is illustrated by the thick arrow. The inset shows the effects of different source processes that have been proposed for Italian volcanoes: 1) increasing phlogopite content of the mantle source (Conticelli and Peccerillo 1992) and 2) increasing pressure, decreasing degree of partial melting and decreasing $\mathrm{H}_{2} \mathrm{O} / \mathrm{CO}_{2}$ ratio of the mantle source (Panza et al. 2007 and references therein).

Figure 6:

Comparison of experimental residual liquids with primitive melt inclusions data from Mt. Vesuvius (after Cioni 2000; Cioni et al. 1998; Fulignati et al. 2004; Marianelli et al. 1995, 2005) in a TAS diagram (a) and in a $\mathrm{CaO} / \mathrm{MgO}$ vs. $\mathrm{SiO}_{2}$ diagram (b). Experimental data (filled circles) are from olivine doped experiments at $1150^{\circ} \mathrm{C}$. Primitive melt inclusions data $(\mathrm{MgO}>6 \mathrm{wt} \%)$ are grouped according to the eruptive period to which they belong (indicated in the legend). Period II and III defined after Ayuso et al. (1998) as in Fig.3a. Melt inclusions in high temperature skarn $(\mathrm{MgO}=3-4.5 \mathrm{wt} \%)$ are also shown (empty squares, Fulignati et al. 2004). In both diagrams ( $a$ and $b$ ) the evolution of the experimental residual liquids with increasing calcite addition, up to $15-17 \mathrm{wt} \%$, well reproduces the trend of melt inclusion data. 
The arrows indicate how calcite addition, crystallization of leucite, clinopyroxene and olivine shift the liquid composition in the diagram. For all eruptive period, the most primitive compositions are the silica richest.

\section{Figure 7:}

Geochemical modeling of $\mathrm{Sr}$ at Mt. Vesuvius. Natural compositions of recent shoshonites (SHO; Di Renzo et al. 2007), 1944 phontephrites (PTph 1944; Del Moro et al. 2001; Civetta et al. 2004), cognate cumulates of clinopyroxenite associated to the shoshonites and the phonotephrites (CPX SHO and CPX 1944 respectively; Del Moro et al. 2001; Piochi et al. 2005; Di Renzo et al. 2007) and Campanian limestones (L1 and L2; Piochi et al. 2006; Di Renzo et al. 2007) are shown. Open squares represent the mechanical mixing between 1944 phonotephrite and clinopyroxenite (a square every $20 \mathrm{wt} \%$ ), illustrating the effect of cpx crystallization on the $\mathrm{Sr}$ content of the magma. The dotted line simulate the mechanical mixing between the shoshonite and the two limestones (a dot every $5 \mathrm{wt} \%$ ), illustrating the effect of limestone addition on the Sr content and isotopic composition of the magma. A combination of ca. $50 \mathrm{wt} \%$ of CPX and $50 \mathrm{wt} \%$ of PTph is reproduced by mixing $15-20 \mathrm{wt} \%$ of L2 with the shoshonite, whereas a combination of ca. $35 \mathrm{wt} \%$ of CPX and $65 \mathrm{wt} \%$ of PTph is reproduced by mixing $45-50 \mathrm{wt} \%$ of $\mathrm{L} 1$ with the shoshonite. The theoretical position (see text for explanation) of experiments \#7-4 to 7-6 (open circles) and \#8-4 to 8-6 (filled circles) illustrate the combined effect of carbonate assimilation + cpx crystallization (mechanism 4 in the text). 


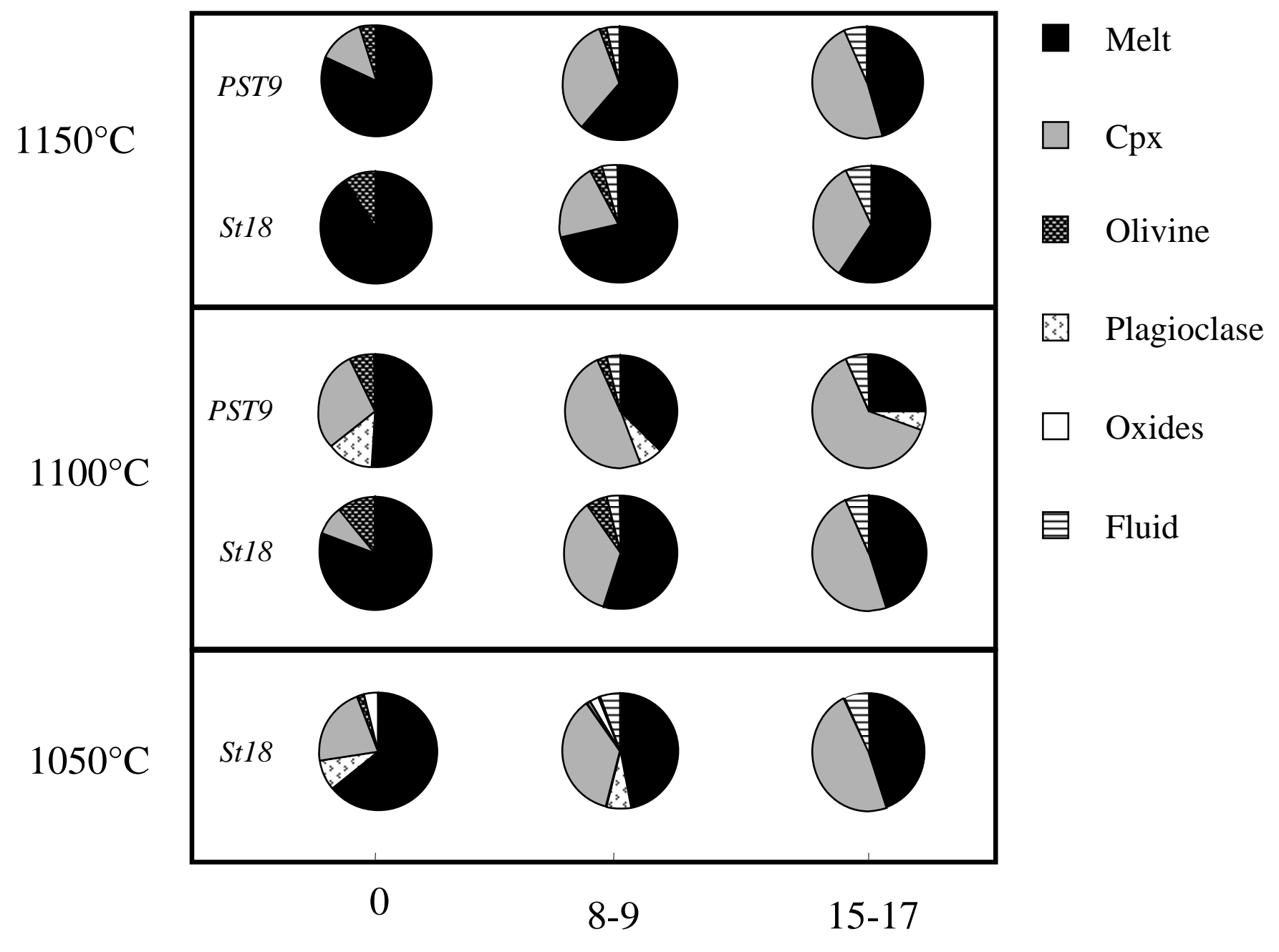

wt $\%$ calcite added

Fig. 1 


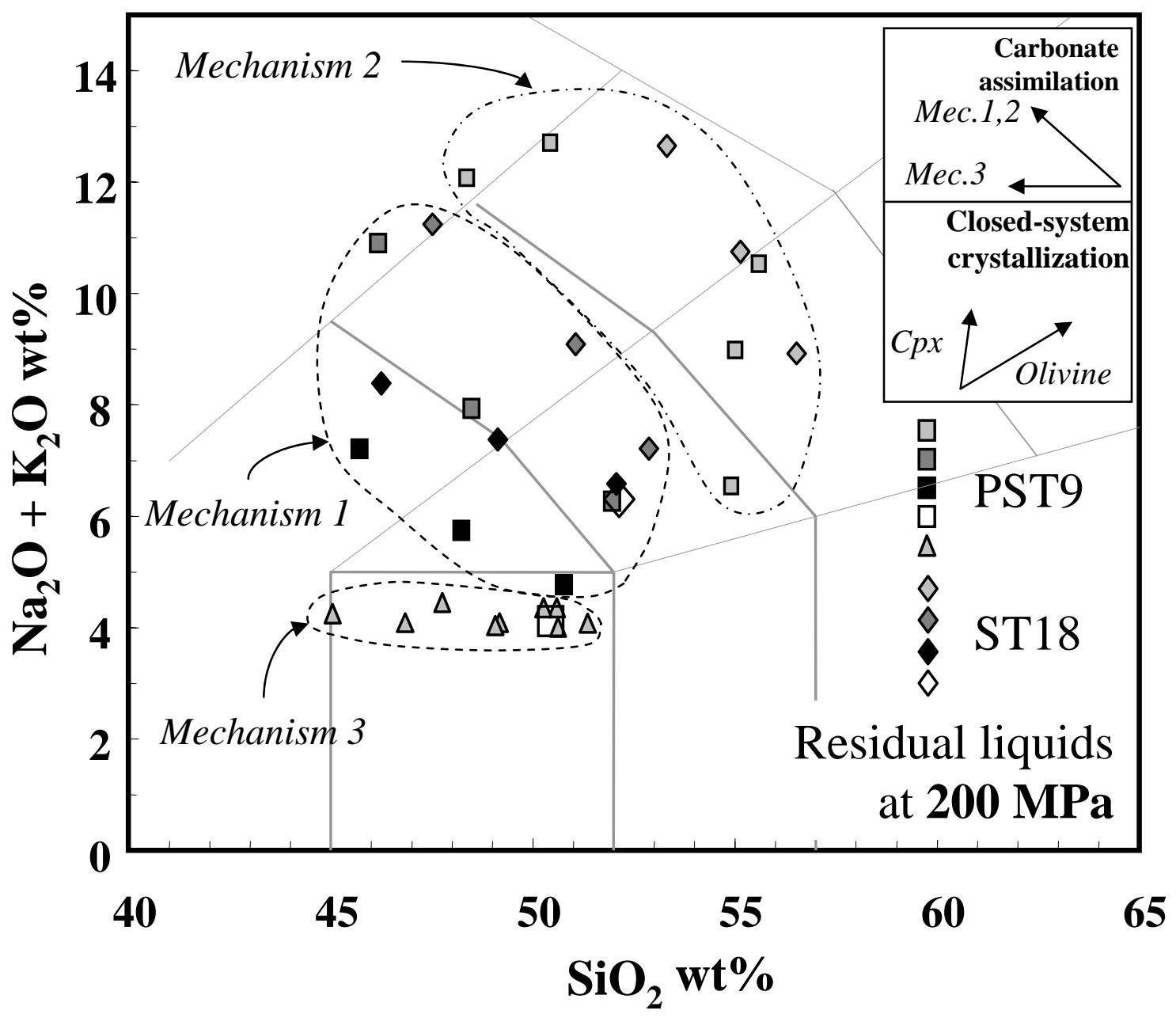

Fig.2 


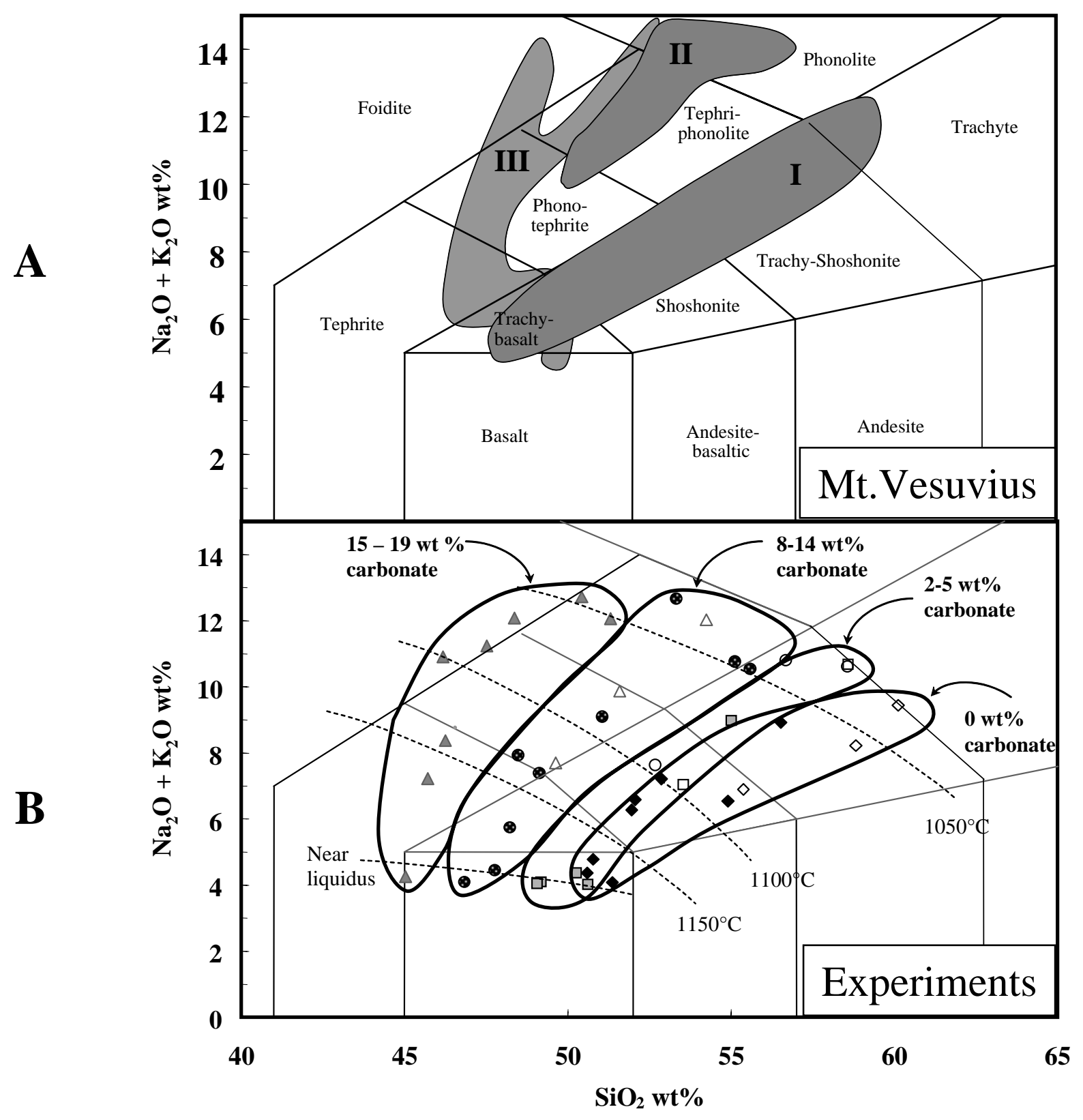

Fig. 3 


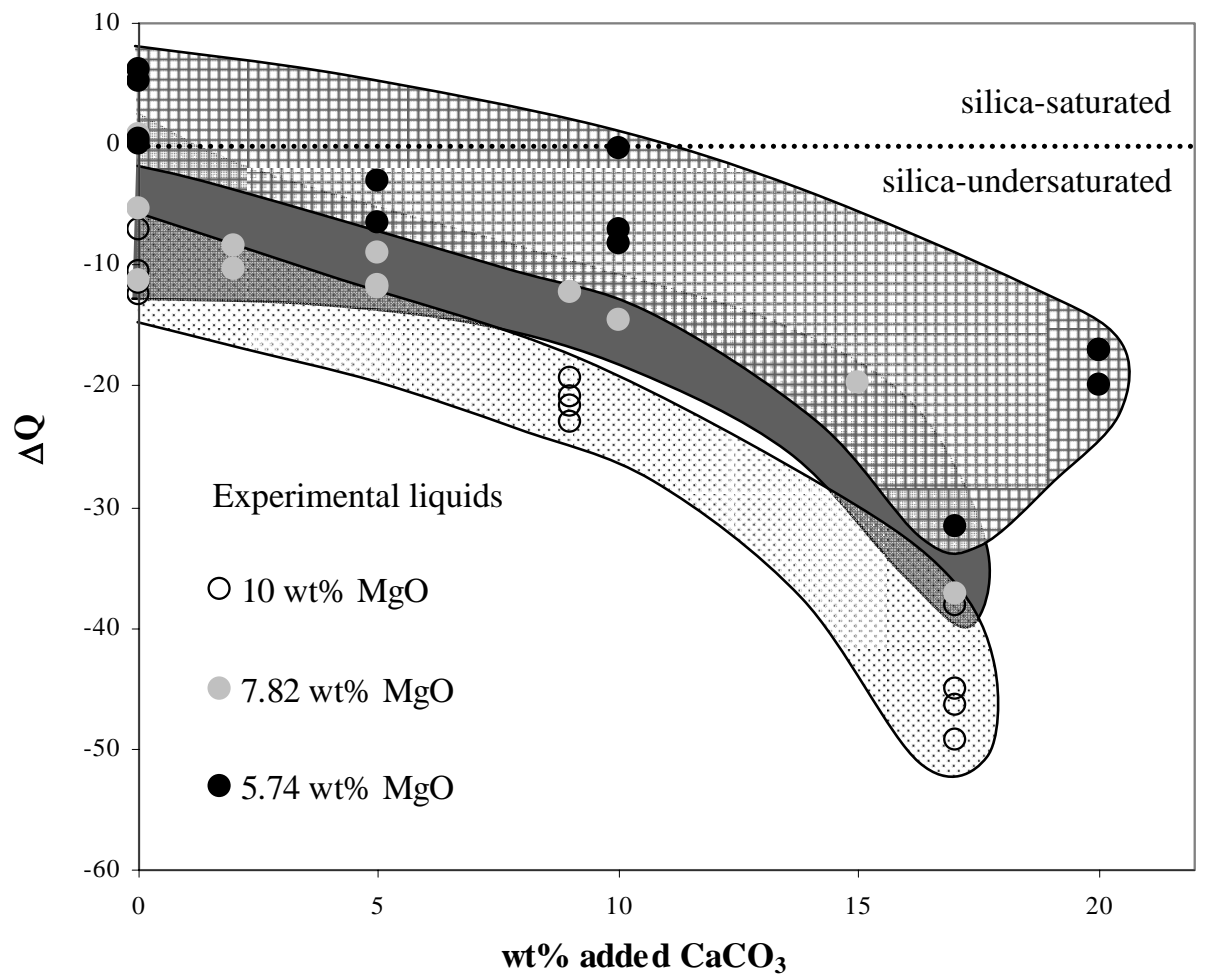

Fig. 4 


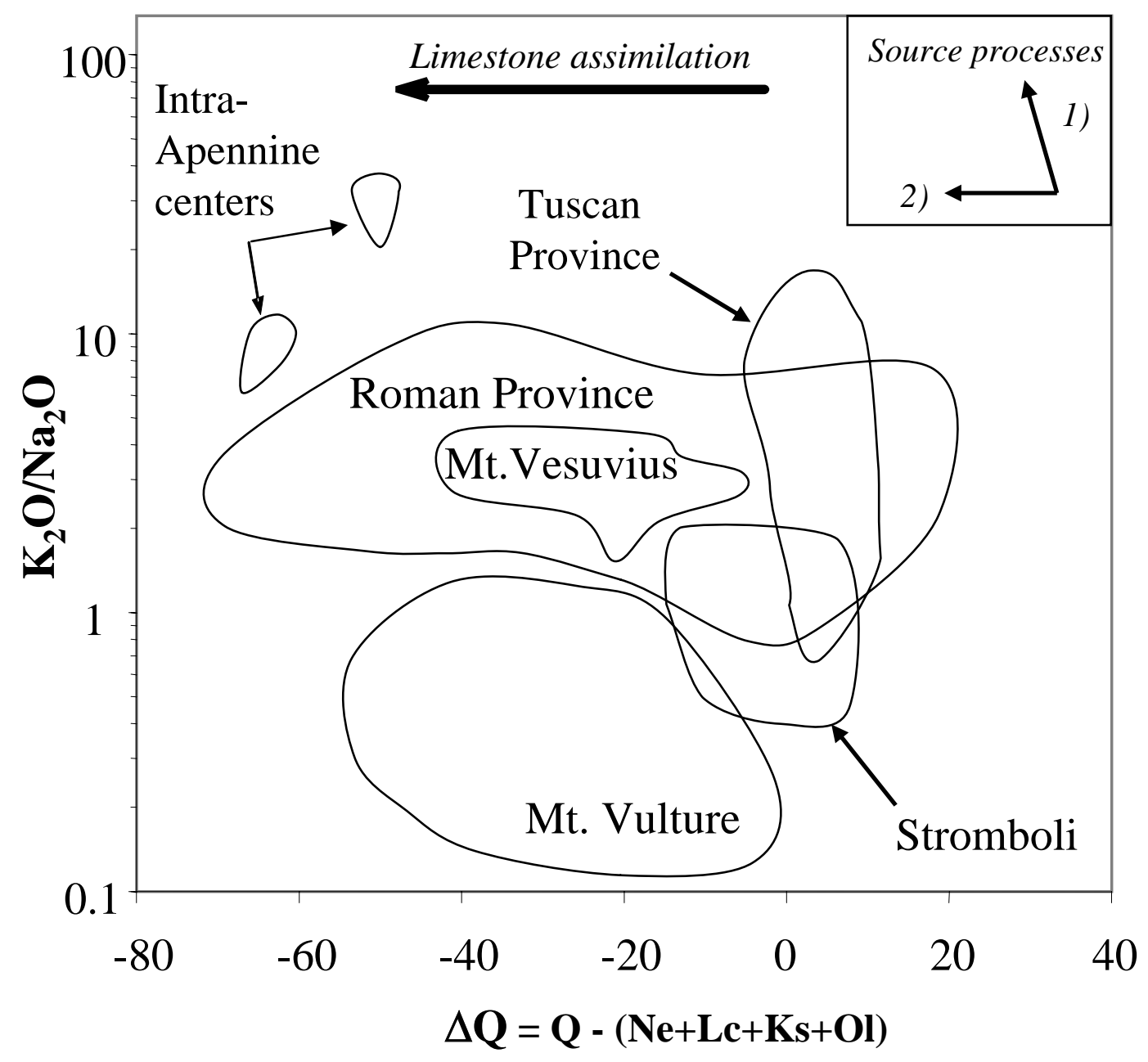

Fig. 5 
A
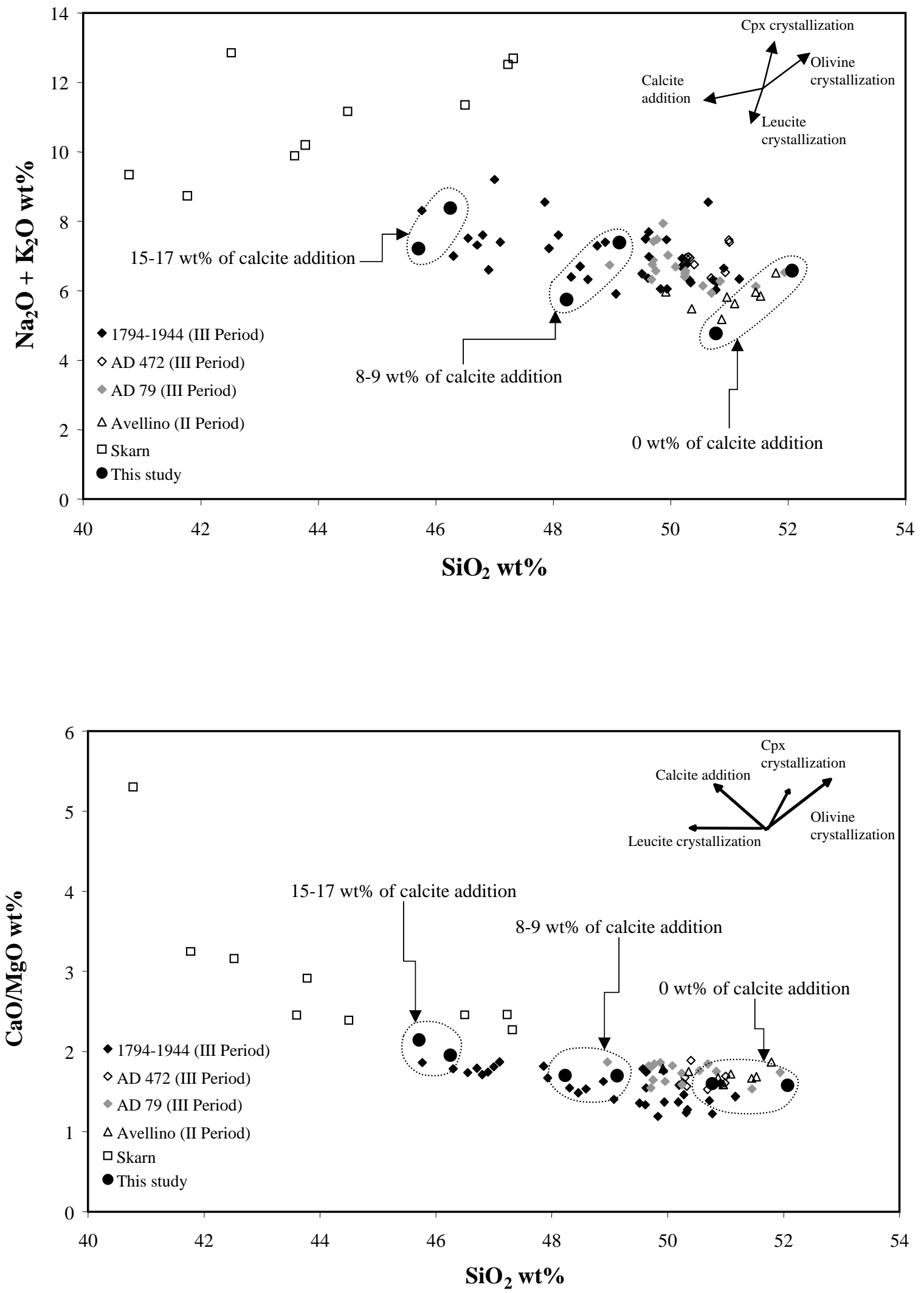

Fig. 6 


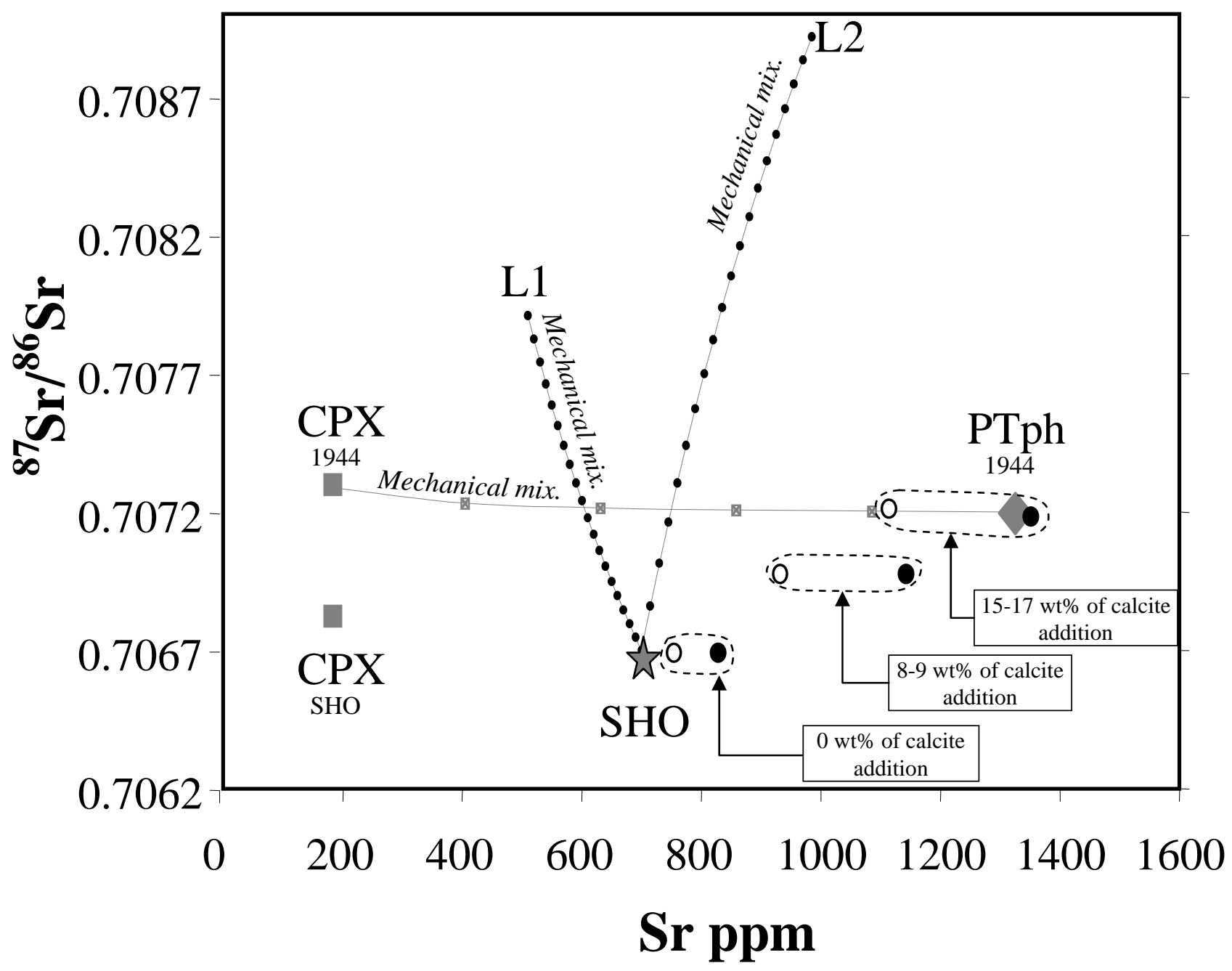

Fig. 7 